\title{
Small States Foreign Policy: The Case of Kosovo
}

\author{
MSc. Alfred Marleku \\ University of Prishtina, Kosovo \\ E-mail: alfredmarleku@gmail.com
}

\section{Doi:10.5901/mjss.2013.v4n2p287}

\begin{abstract}
:
Enormous changes have occurred in international system in the last twenty years. As a result, the number of Small States in international system has grown rapidly. These processes have had strong and noticeable impact in the foreign policy of all states, particularly in the foreign policy of small states. This paper examines Kosovo's foreign policy behavior as an independent state. By conducting an in depth analysis in this case study, paper attempts to clarify which are the main dominant sources that influence more the Kosovo's foreign policy behavior. Foreign policy of Kosovo as a small state was characterized by two main behaviors: tendency to secure multinational agreements and join multinational institutions and the tendency to rely on larger states, especially on USA, in order to ensure protection, partnership and resources. The main variables which have proved to have significant impact in Kosovo's foreign policy behavior are systemic variables: a category which is based mainly in nonhuman aspects of a society's external environment or in any kind of action occurring abroad and influencing the choices made by officials.
\end{abstract}

Keywords: small states; interdependence; foreign policy behavior; multinational institutions.

\section{Introduction}

International system in the last twenty years has experienced enormous changes. These processes have had strong and noticeable impact in the foreign policy of all states around the globe, particularly in foreign policy of small states. Today small states enjoy more international prestige and visibility than at any other time in world history. In most cases their physical security is issued, while the rise of transitional efforts such as the European Union EU, the Free Trade Agreement of the Americas, and the North Atlantic Organization (NATO) put them on a legal and diplomatic footing with larger countries (Hey, 2003).

The vast majority of states who constitute international system are small states. After eight years under the administration of United Nation Mission in Kosovo (UNMIK) ${ }^{1}$, and after about two years of negotiation for solving the final political status - with the proposal of United Nation (UN) mediator - on February $17^{\text {th }} 2008$ Kosovo declared its independence and became part of the vast majority of states in the international system which are considered small states. During the UNMIK administration foreign affairs of Kosovo where considered as a "reserve competence": UNMIK had the right and responsibility to sign on behalf of Kosovo all treaties and agreements. Whereas, from the "Comprehensive Proposal for the Kosovo Status Settlement" Kosovo gained monitored independence which created the opportunity to have complete competences on the external policy (2007).After the declaration of its independence, Kosovo established its Ministry of Foreign Affairs, as a leading institution responsible for the development and coordination of issues in relation to other countries. Kosovo declaration of independence is considered as a turning point of its history which resulted in growing pressure on its leadership to 'reinvent' its foreign policy accordingly. Calls have been issued for the formulation of the new strategies and policies that would create necessary conditions that will promote Kosovo as a new born state in international relations. In this regard, the main objective of Kosovo's foreign policy was to get as many recognitions as possible from other states in order to consolidate its international position and standing as a democratic, stabile and successful state.

\footnotetext{
1 United Nation Interim Administration Mission in Kosovo was the interim civilian administration in Kosovo under the authority of United Nations. The mission was established on 10th of June 1999 by Security Council Resolution 1244. While UNMIK still exists, it does so in minor role following the creation, in December 2008, of the European Mission Rule of Law mission in Kosovo (EULEX). EULEX assists and supports the Kosovo authorities in the rule of law area, specifically in the police, judiciary and customs areas.
} 
The aim of the presented paper is to examine Kosovo's foreign policy behaviour as an independent state: what are the sources of Kosovo's foreign policy? Which of these sources are more dominant and how these sources influence Kosovo's foreign policy behaviour? These are some of the questions that this paper address and which will be answered throughout the paper.

The main theoretical framework used in this paper will be based on the theories of James N. Rosenau. He grouped the potential forces that are influential in foreign policy of small states into five categorical sources: (1) external (global), (2) environmental, (3) societal, (4) governmental setting, (5) roles occupied by the policy makers and the individual characteristics of the policy making elites. These sources are considered independent variables which influence the foreign policy behaviour of a particular state.

Based on the aims of this thesis and referring to the established body of literature on international relation theories, the following hypothesis is subject of analysis: If systemic variables - a category which is based on nonhuman aspects of a society's external environment, or in any other actions occurring abroad and influencing significantly choices made by officials - predominates foreign policy of a country, then the ability of a small state to achieve its goals and objectives in international relation independently, without the help and support of other great state, are almost inexistent.

The paper is divided in three main parts. Part one delves into the literature on the small states and foreign policy in a research for definition and better understanding of the concept of small states and their foreign policy behaviour within the international relation. Part two outlines methodology that has been used to conduct the research including detailed reasons which explain what makes these methodological approaches more appropriate than others. Part three puts on ground the analysis of Kosovo's foreign policy behaviour and views it through critical lenses by providing suggestions to the Kosovo policy makers that would be useful in order to improve Kosovo's foreign policy according to its strategic needs and interests.

\section{Theoretical consideration}

\subsection{Defining small states}

Most of the literature which deals with the issues of small states - theoretically or practically, externally or internally always was focused on the issue of definition. Yet, despite decades of study, no satisfactory definition has been found (Hey, 2003). Furthermore, some scholars concluded that the definitional problems of small states were so great as to make the concept of smallness useless as an analytical tool (Hey, 2003). In this regard, "size", as a quantitative measure, has been considered important element in framing an operational concept of small states. However, most of the scholars find necessary to employ rational factors which are based on underlying the notion that the essence of "smallness" is either lack of influence on the environment, or lack of immunity against influence from it, or both (Hower, 2008).Beside the blurredness that encompasses the issue of definition of small states, no one can question the existence of them in international system. Small states constitute the vast majority of states in international system. This composition of the international relation system exists at least from the last 350 years, i.e. since the Peace of Westphalia (Mass, 2007).

The graphic below presents the trend of small states emergence since the Peace of Westphalia (1648). As the graph shows, small states have constituted a majority in the Westphalia system, although admittedly to varying degree (Mass, 2007). 


\section{Small States Since 1648 (Mass, 2007)}

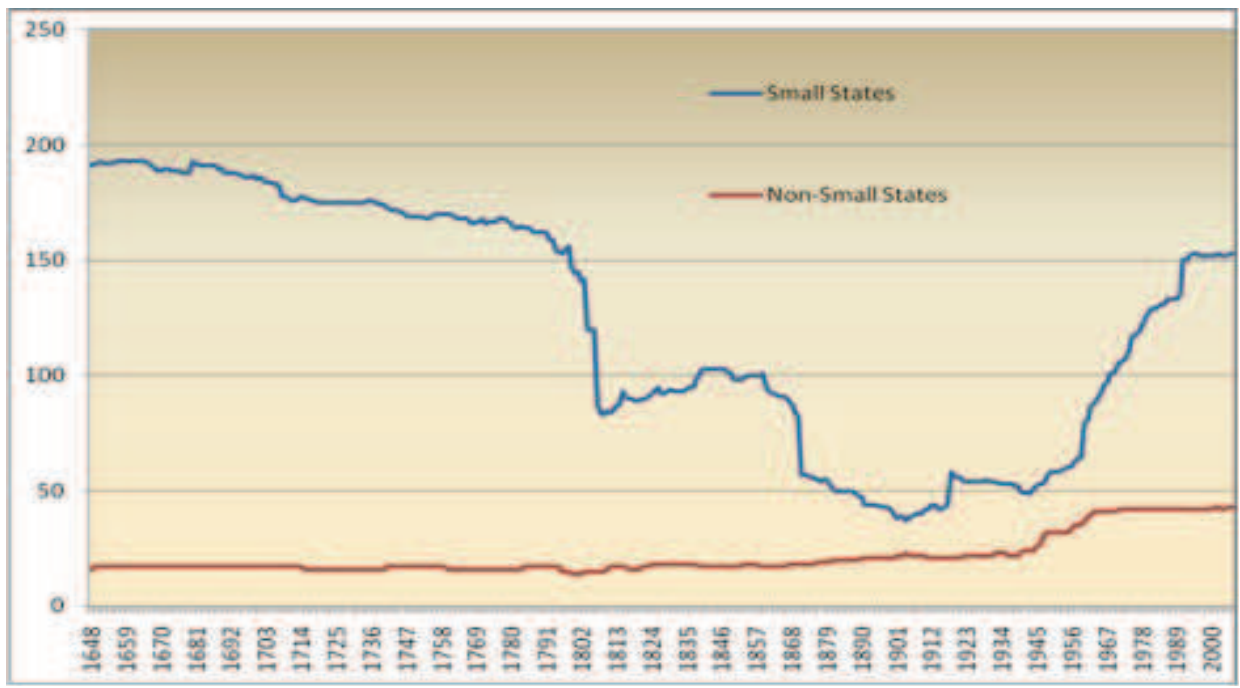

If we categorize them according to their size, small states today comprise the biggest number of states in international system. According to Daniel Thurer, quoted from the Jeanne A.K. Hey book, if we look at the today's world, we can easily discover that it is a world made up of small states (2003). However, the main question still remains: how small states can be defined? Which are these particular characteristics and features which pursue scholars to the deduction in distinguishing and labeling a group of states as small, medium, and others as large states?

Smith, Pace and Lee raise a crucial question: should small states be categorized along geographic, demographic or economic lines; or do institutions, resources and power hold the key? (2005). Jeanne A.K. Hey argues that attempts to define small states have included geographical size, population size and a country's degree of influence in international affairs (2003). Most of the studies conducted so far in the field of small states have concluded that they have generally three communities in mind when they speak of small states: "Microstate - states with a population with less than one million inhabitants, such as the former British colonies in the Caribbean; small states in the developed world - especially Austria, Belgium, Luxemburg, the Nederland and the Switzerland; and small states in the so-called third world, including former colonies in Africa, Asia and Latin America - many of which are larger than states mentioned in the two first categories described above" (Hey, 2003, p. 2).

Nonetheless, none of the up mentioned categories are explicit and clear, nor there is and general agreement which of them gives the proper coordinates how to define small states. It is not always the case that Microstates are states with a population with less than 1 million inhabitants. There are cases where the threshold is set higher: for instance, 1.5 million inhabitants. Or lower: for instance, 300,000 or 100,000 inhabitants. Or, if it is seen alternatively, "a micro state is simply viewed as a characterised by a size so diminutive as to invite comment" (Steinmentz \& Wivel, 2010, p. 6). The second categorization of states - small states in developed world - according to Robert Steinmetz and Anders Wivel, is done by using a number of different - often incompatible - criteria leading to confusion over how to know a small state when we see one (2010). In this regard, Raimo Vayrynen in his study: On the Definition and Measurement of Small Power Status identifies two main approaches for dealing with small states. The first approach of the defining criteria is the distinction between: objective or subjective (Vayryen, 1971). Some of the objective criteria, which are measurable, are: the size of the population, the size of territory or the level of GDP. On the other hand, the subjective criterion, much more difficult to measure, is the perception of domestic or foreign elites. In addition to this, as Raimo Vayrynen argues, the second approach of the defining criteria of small states is the distinction between: endogenous i.e. internal characteristics of a country and exogenous i.e. country's relations with other states (1971). The third categorization of the small states as mentioned above - is the group of the small states, of so called, third world. This categorization is unclear, very complex and foggy for the following reason: small states in the third world usually have much larger populations than states in the developed countries, because population size is taken as a proxy of a range of other economic characteristics - all of which are deemed to bestow particular vulnerabilities on small states (Steinmentz \& Wivel, 2010). 
Even though "size" by many authors is considered as objective and measurable variable to define small states, the consideration of "size" in interstate relations has not been the subject of debate Authors still argue upon the issue of what are the characteristics distinguishing a state as a "small". Beside the fact that the concept of "small states" is used a lot in literature of international relation, there is still no established consensus on a classification schema (Hower, 2008). For this reason, scholars studying small states have created categories of states such as: 'micro,' 'small,' 'weak,' 'middle,' 'great,' 'strong,' and 'supper' based on the indicators such as: population, GNP and military capacity (Hower, 2008).

In this regard, Michael Handle, quoted from the Sara Beth Hower, consider other additional factors which make the definition of "small states" blurred and hardly differentiable between small, low-level middle, high-level middle, large and great powers. According to the same author, the distinction becomes more complicated when factors as nuclear weapons and economic prosperity are considered. "Pakistan, for instance, may be considered geographically and economically small but possesses a population more than double that of Great Britain and France (often termed great powers because of their modern armed forces and nuclear weapons) and enough nuclear capability to strike neighbouring India" (Hower, 2008, p. 7).

Erling Bjol points out that a state is only small in relation to a greater one. For instance, Belgium may be a small state in relation to France, but Luxembourg is a small state in relation to Belgium, and France a small state in relation to the U.S. Bjol argues that to be of analytic use small state should therefore be considered shorthand for a state in its relationships with greater states (Hower, 2008).

On the other hand, there are theorists of small states which - taking into the consideration that size is a relative concept - claim that the concept of the small state is based on and derives from the idea of perception. In other words, if a state's people and institutions generally perceive themselves to be small, or if other states' peoples and institutions perceive that state as small, it shall be so considered (Hey, 2003). This idea is supported strongly by Robert Rothstein and Robert $\mathrm{O}$. Keohane. Both of them argue that psychological dimension should complement any objective criterion by which to define smallness. According to Rothstein, quoted from the Robert Keohane review: Lilliputians' Dilemmas: Small States in International Politics, "a small power is a state which recognizes that it cannot obtain security primarily by use of its own capabilities and that it must rely fundamentally on the aid of other states, institutions, processes, or developments to do so" (1969). He continues his arguments explaining that the Small Power's beliefs in its inability to rely on its own means must also be recognised by the other states involved in international politics (Keohane, 1969). Putted differently, small states are what they are not. Even though, Robert Keohane gives different view which comparing with Rothstein, nevertheless, it draws to the same conclusion which is based on the idea of perception. According to him, a small state is "a state whose leaders consider that it can never acting alone or in small group, make a significant impact on the system" (1969). Based on the arguments mentioned above it can be deducted that the smallness of particular state is not a product of any kind of objective definition which can be measured, but the idea of its size - which is always relative - is based on the perception. In fact, the research on small states, despite its attempts at formal definition, is best characterised by an "I know one when I see it" approach to choosing its subjects of inquiry (Hey, 2003).

Nevertheless, there are a lot of authors and researchers dealing with small states which argue that the most measurable and operative definitions of small states are those referred to the population as the main indicator of size. The 1997 Commonwealth Advisory Group Report: A Future for Small States: Overcoming Vulnerability argues that the criterion has been achieved by defining small state as one with a population of around one million or less inhabitants (Commonwealth Advisory Group Report, 1997).However, this definition, which has been used since 1985, and, as the report says - has stood the test of time very well (1997) - is reviewed. "Facing a large increase of the world population, a revised upper limit of the 1.5 million is taken as a new cut-of point." (Commonwealth Advisory Group Report, 1997). The World Bank uses the same indicator for defining/measuring the small states. According to the WB small states is a term applied to a diverse group of sovereign developing countries-"some quite wealthy, some very poor; some islands or groups of islands; some land locked; many with populations of 1.5 million Inhabitants" (The World Bank-Projects and Operations, 2010).

There are two conceptual approaches dealing with small states adopted in this paper: subjective and objective approach. According to the subjective approach, small states are defined as how they see themselves and others define them. This approach is supported strongly by Keohane and Rothstein according to whom psychological dimension complement any other objective approaches by which small states are defined. Kosovo is perceived by its population, by its political elite and by other countries of international system as a small state. Whereas, based on the objective approach, indicators are measurable such as: the size of the population, the size of territory of the level of GDP. In this regard, the definition offered by the World Bank can be considered more accurate and operative. According to this definition small states refer to the population - as the main indicator of size - with the 1.5 million inhabitants. "The 
population of Kosovo in total estimation is around 1.8 million; its area is: 10,887.00 square kilometers and its GDP per capita referred to International Monetary Fund is: 2,750 USD" (U.S. Department of State, 2010).

\section{Small states foreign policy behaviour}

Different authors concerned with analyses of small state foreign policy, achieved to identify a multitude of behaviours that small states either do, or are expected to exhibit (Hey, 2003). In this regard, the most commonly quoted behaviours identified brought to the conclusion that small states in most of the cases tend to:

- Exhibit a low level of participation in world affairs;

- Address a narrow scope of foreign policy issues;

- Limit their behaviour to their immediate geographic arena;

- Employ diplomatic and economic foreign policy instruments, as opposed to military instruments;

- Emphasize international principles, international law, and other "morally minded" ideals;

- Secure multinational agreements and join multinational institutions whenever possible;

- Chose neutral position;

- Rely on superpowers for protection, partnerships and resources;

- Aim to cooperate and avoid conflicts with others;

- Spend a disproportionate amount of foreign policy resources on ensuring physical and political security and survival (Hey, 2003).

Even though the list summarises most of the behaviours that small states tend to have in their performance in international relations, nonetheless scholars found out that the list faces two main obstacles. Firstly, it is too long to be meaningful, that is, to act as a guide for indentifying and predicting how small states will act, and secondly, it is selfcontradicting: it tells us that small states rely on superpowers for resources and protection, indicating an alliance, but also that they choose neutrality (Hey, 2003). Most of the authors are concerned with the issue whether these numerous and contradictory behaviours emerged among small states mean that there can be no general and acceptable theory which encompasses the essence of small foreign policy behaviour? The answer to this question depends on whether scholars can identify the conditions under which small states choose among behaviours available to them (Hey, 2003).

\section{Variables that influence foreign policy}

James N. Rosenau - considered as the father of comparative foreign policy - suggested that "the explanatory factors needed to account for foreign policy behaviour would vary according to three traits: the size, the level of development and the political system of any given state" (Hey, 2003, p. 9). In his book: The Study of World Politics: Theoretical and Methodical Challenges, nearly four decades ago, he developed a pre-theory of foreign policy organized around five clusters of variables at five level of analysis: (1) the individual; (2) role; (3) governmental; (4) societal and (5) systemic level. According to Rosenau, the essential thrust of the pre-theory involved estimating the relative "potency" of the different types of variables for any country and then assessing how a particular country might conduct itself abroad in response to diverse situations (2006).

Starting with the individual variable, "it includes the characteristics unique to the decision-makers that determine and implement the foreign policies of a nation" (Rosenau, 2006, p. 200). This cluster of variables - known also as idiosyncratic - include all those aspects of a decision-maker - his values, talents and prior experience - that distinguish his foreign policy choices, or behaviour, from those of every other decision-maker (2006). Rosenau takes as an example the De Gaulle's vision of a grand and glorious France or the political skills and abilities that Khrushchev possessed.

The second set of variables - role variables - refers to the external behaviour of officials that is generated by the roles they occupy and that would be likely to occur irrespective of the individual characteristics of the role occupants (2006). Regardless the idiosyncrasies of a decision-maker, due to the legal sanctions and existing norms, they have to act according to the role they have form their position. In spite of of who he/she is, for example, the Ambassador who represents Kosovo to the United Nations, he/she is likely to defend the Kosovo position, and not his/her individual position.

The governmental variables refer to those aspects of a government's structure that limit or enhance the foreign policy choices made by decision-makers (Rosenau, 2006). In this regard, the relationships between two state organs executive and legislative - are crucial. The governmental variables, in other words, is focused in the means that policy makers use or are likely to use in order to accomplish particular objectives in foreign affairs. 
As for systemic variables, these include any nonhuman aspects of a society's external environment or any actions occurring abroad that condition or otherwise influence the choice made by officials (Rosenau, 2006). Thus, this variable of the pre-theories of foreign policy is based on the characteristics of international system and in the way that states and non state actors behave. This approach was developed during the Cold War era; that is why Rosenau takes as examples of systemic variables that can shape the decisions and actions of foreign policy officials the geographical "realities" and ideological challenges from potential aggression. To conclude, the behaviour and specific (re)actions of particular state abroad, are influenced by other sates' actions but also by the status in the international system.

\section{Methodology}

\subsection{The case study approach}

This paper was conducted using two research strategies: (1) a case study approach and (2) discourse analysis. The case studies are one of several approaches which are extremely popular and widely used in social sciences. Scholars argue that case study, as a research strategy, is used in many situations enabling researchers to focus on a single individual, group, community event, policy area or institution, and study it in depth, perhaps over an extended period of time (Burnham et al., 2008) "Not surprisingly, the case study has been the common research strategy in psychology, sociology, political science, social work, business and community planning (Yin, 2003, p. 1)" In general, case studies are the preferred strategy when "why" "how" questions are being posted, when the researcher/investigator has little control over events, and when the focus is over contemporary phenomenon (Yin, 2003). Scholars argue that while, both quantitative and qualitative data can be generated by case study design, the approach has more of qualitative feel to it as it generates a wealth of data relating to one specific case (Burnham et al., 2008). "In order to have a wider impact than that of merely being a detailed account of a unique case, a strong theoretical dimension is often incorporated into the case study design (Burnham et al., 2008, p. 63)."

\subsection{The object of analysis}

The object of analysis in this paper is the foreign policy behaviour of small states, with special focus in the case of Kosovo. Since the concept of smallness itself is very relative concept, most of the literature on the small states spends most of space on the issue of definition. For this reason, a considerable part of this paper is dedicated to the theoretical consideration of the concept of small states, foreign policy and its variables. The second part of the paper is focus in analysing the case of Kosovo's foreign policy. After a short description of the Kosovo's road to independence, foreign affairs of Kosovo under the UNMIK administration and within the Ahtisari Proposal, the analysis is focused on the Kosovo's Ministry of Foreign Affairs. Beside the overall analysis done to the ministry, the objective was focus on two most important documents which determine the Kosovo's foreign policy: "Kosovo Foreign Objectives" and the "Programme and Core Objectives of the Ministry of Foreign Affairs". The analysis of these documents was carried out by using Discourse Analysis, as a specific approach of Qualitative Methods. Discourse analysis is focused of text as a social practice and on the resources that are drawn on to enable those practices. According to the scholars, the discourse analysis approach does not analyse and describe only the textual structures. In other words, as the Dutch scholar Teun A. Van Djik argues, the major aim of discourse analysis is to analyze text and context (Van Dijk, 1988).

\section{Kosovo: Road to independence}

Kosovo had been an autonomous province of Serbia in the Socialist Federal Republic of Yugoslavia established by Marshall Josip Broz Tito after the World War II. Within the Yugoslav Constitution of 1974 Kosovo achieved the status of a Socialist Autonomous Province. Kosovo remained part of Serbia, but it was almost a full federal entity: it had its own national bank, parliament, government, and police. In other words, Kosovo Albanians were more or less in full control of Kosovo (Judah, 2008). In 1981, riots broke out and were violently suppressed after Kosovo Albanians demonstrated to demand that Kosovo be granted full Republic status (U.S. Department of State, 2010). After the Slobodan Milosevic came to power in the late 1980 - by exploiting Serbian nationalism and the question of Kosovo - in 1989 he started to eliminate Kosovo's autonomy and imposed direct rule from Belgrade. One of the first steps of his regime was to fire most of the ethnic Albanians state employees, whose jobs were then assumed by Serbs (U.S. Department of State, 2010). In early 1990s, Kosovo Albanian leaders, led by the intellectual Ibrahim Rugova, began a peaceful resistance movement by 
establishing a parallel system of institutional organization. "The movement was especially strong among Albanians abroad and heavily financed by them" (Carlo, 2003, pp. 167-182). When this movement failed to give results, an armed resistance emerged in 1997, which was named as Kosovo Liberation Army (KLA) (U.S. Department of State, 2010). The KLA's main goal was to secure the independence of Kosovo.

During the 1998, Milosevic began his police and military campaign against KLA, which included widespread atrocities against civilians. As Milosevic's ethnic cleansing campaign progressed, over 800.000 ethnic Albanians were outcaste from their homes and deported in Albania, Macedonia and Monte Negro. Intense international mediation efforts led to the Rambouillet Accords, which called for Kosovo autonomy and the involvement of NATO troops to preserve the peace. Milosevic's failure to agree to the Rambouillet Accords triggered a NATO military campaign to halt the violence in Kosovo (U.S. Department of State, 2010). This campaign consisted primarily of bombing of the Federal Republic of Yugoslavia, including Belgrade, and continued from March till June 1999. After 78 days of bombing, Milosevic capitulated. Shortly thereafter, the UN Security Council adopted Resolution 1244/1999, which suspended Belgrade's governance over Kosovo, established the United Nations Interim Administration Mission in Kosovo (UNMIK), and authorized a NATO peacekeeping force. "Resolution 1244 also envisioned a political process designed to determine Kosovo's status" (U.S. Department of State, 2010). UNMIK guided Kosovo in establishing new institutions in both levels of governance: municipal and central, held free elections, and established a multi-ethnic Kosovo Police Service (KPS). The Kosovo Liberation Army (KLA) was demobilized, with many of its members incorporated into the Kosovo Protection Corps (KPC)(U.S. Department of State, 2010). With the time passing, UNMIK began to transfer more governing competencies to Kosovo authorities.

Martti Ahtisaari, former president of Finland, in 2005 was appointed by the United Nations Secretary General Kofi Annan to lead a future Kosovo's status process. In the same year Ahtisaari's diplomatic efforts addressed a broad range of issues important to Kosovo's future, including: decentralizing local government, protecting cultural and religious heritage in Kosovo, economic issues, and safeguarding the rights of minorities. Over the course of 2006 and early 2007, Ahtisaari brought together officials from Belgrade and Prishtina to discuss these practical issues and the question of status itself (U.S. Department of State, 2010). Ahtisaari subsequently developed a comprehensive proposal for Kosovo's future status, which set forth a series of recommendations on Kosovo's democratic governance and substantial protections for minorities (U.S. Department of State, 2010). Ahtisaari also recommended that Kosovo become independent, subject to a period of international supervision. He proposed that a new International Civilian Office (ICO) be established to supervise Kosovo's implementation of its obligations under the Ahtisaari Plan. A European Union (EU) rule of law mission (EULEX) would be deployed to focus on the police and justice sector, while a NATO would continue to provide safe and secure environment. Prishtina accepted the Ahtisaari recommendations, but Belgrade rejected them (U.S. Department of State, 2010).

Kosovo declared its independence from Serbia on February 17, 2008. In its declaration of independence, Kosovo committed to fulfilling its obligations under the Ahtisaari Plan, to embrace multi-ethnicity as a fundamental principle of good governance, and to welcome a period of international supervision (Kosovo Declaration of Independence, 2008).

\section{1 Foreign affairs of Kosovo under the UNMIK administration}

Foreign affairs and foreign policy of Kosovo within the Constitutional Framework for Provisional Self-Government were treated as a "reserve competence" of UNMIK administration. During this period, conflicting approaches prevailed in Kosovo foreign affairs - the traditional international law approach, manifested through the recognition of the formal sovereignty of Belgrade over Kosovo, was countered with the practical recognition of UNMIK/Kosovo as an independent international actor with limited treaty making powers (Peci, 2007).

During this period, Kosovo has achieved to enter and to be part of several international bodies in different fields, with a special focus on those dealing with: economy, security and energy such as: Regional Free Trade Area Agreement of South Eastern Europe (UNMIK, 2010) and other free trade area agreements with neighbouring countries such as with Albania and Macedonia. Beside this, another important agreement which UNMIK signed on behalf of Kosovo was: "Treaty establishing the Energy Community between the EU and South Eastern Europe" signed in Athens in October 2005. The Treaty creates a single regulatory framework for energy trading across borders. At its initiative, UNMIK has concluded agreements in the sphere of security with the Republic of Macedonia on police and cross border cooperation, joint verification of hidden persons and exchange of forensic expertise and cross-boundary repatriation of identified remains. UNMIK also signed agreements with Albania and Montenegro on police cooperation (Peci, 2007). 
Beside the fact that UNMIK signed a significant numbers of agreements and treaties on behalf of Kosovo agreements which improved the interaction of Kosovo with their parties, mainly in economical fields - there was little done in building proper capacities of Kosovo institutions in foreign affairs and foreign policy. This fact produced consequent obstacles in the following years when the Kosovo Foreign Ministry was established.

\subsection{Foreign affairs of Kosovo within the "Ahtisari Package"}

After 1 year of intensive negotiations between Kosovar and Serbian team, the mediator of these talks, Martti Ahtisaari, in March 2007 presented to the Secretary-General of UN his plan for Kosovo, in the form of two documents: the four-pages "Report of the Special Envoy of the Secretary-General on the Kosovo's Future Status" and the 63 pages "Comprehensive Proposal for the Kosovo Status Settlement". According to the Settlement Proposal, Kosovo shall continue to be bound, on the basis of reciprocity where appropriate, by all international agreementsand other arrangements in the areaof international cooperation that were concluded by UNMIKfor and on behalf of Kosovo (Comprehensive Proposal for Kosovo Status Settlement, 2007). Among others, the Settlement Proposal specifically obliges Kosovo to take all necessary measures towards ratifying the European Convention for the Protection of Human Rights and Fundamental Freedoms and its Protocols.

From the Comprehensive Proposal for Kosovo's Status Settlement, Kosovo gained monitored independence, with complete competences on its internal and external policy. According to the proposal, Article 1 point 1.5, "Kosovo shall have the right to negotiate and conclude international agreements and the right to seek membership in international organizations" (Comprehensive Proposal for Kosovo Status Settlement, 2007).

\section{Kosovo's Ministry of Foreign Affairs}

Ministry of Foreign Affairs (MFA) of the Republic of Kosovo was established on March 13, 2008. Its creation is based on Law No. 03/L-044, approved by National Assembly on the Ministry for Foreign Affairs and Diplomatic Service. Seventyfive countries, including the United States and most European states, recognized Kosovo independence (USAID Kosovo, 2010). "The achievement of additional recognitions remains the foremost foreign policy objective of the Government of Kosovo" (Kosovo Foreign Objectives, 2009).

Ministry of Foreign Affairs is responsible for the development and coordination of responsibilities in relation to other countries. It protects the interests of Kosovo in relation with other countries and international organizations, in full coordination with other ministries, depending on their competencies, Office of the President of Kosovo and other institutions of the Republic of Kosovo, in compliance with the Law on the Ministry of Foreign Affairs and the Constitution of Kosovo (Kosovo Foreign Objectives, 2009). "The MFA represents the Republic of Kosovo, and its state institutions, in other countries and international inter-governmental organizations, through the embassies, missions or representative organizations that are determined by the Ministry, in consultation with the President and Prime Minister of Kosovo" (Kosovo Foreign Objectives, 2009).

Two most important laws of Kosovo Ministry of Foreign Affairs are:

- Law No. 03/L-122 - Law on the Foreign Service of the Republic of Kosovo;

- Law No. 03/L-125 - Law on Consular Services of Diplomatic and Consular Missions of the Republic of Kosovo. ${ }^{2}$

These laws provide the detailed basis for the operation of diplomatic and consular missions, the legal authorities for performing services for Kosovo citizens abroad, authorization for program operations of embassies and consulates, the general responsibilities of heads of mission (ambassadors or chargés d'affaires), and the responsibilities of the ministry in directing its diplomatic and consular missions (Law on the Foreign Service of the Republic of Kosovo \& Law on Consular Services of Diplomatic and Consular Missions, 2010).

\footnotetext{
2 Other relevant legislation of Kosovo Ministry of Foreign Affairs include: Law No. 03/L-034 on Citizenship of Kosovo; Law No. 03/L-033 on the Status, Immunities and Privileges of Diplomatic and Consular Missions and Personnel in Republic of Kosovo and of the International Military Presence and its Personnel; Law No. 03/L-126 on Foreigners and Draft Law No. XX/2009 for the State Protocol of the Republic of Kosovo (Kosovo Foreign Objectives, 2009).
} 


\subsection{Foreign policy of Kosovo as an independent state}

What dominated Kosovo Foreign Policy after the Independence was focused on mainly in accomplishing two short term objectives as defined from the "General Objective":

1. Working for recognition of Kosovo by majority of UN member countries and by all of the EU countries and

2. Building effective diplomatic and consular services in the states wherever there is a significant number of Kosovo citizens.

The subsequent analysis of Kosovo foreign policy is focused on examining in detail these two objectives of Kosovo foreign policy. Based on James N. Rosena's explanation of foreign policy variables, systemic level variables of analysis framework - which is referred mainly to non human aspects of a society's external environment - is considered a very important and powerful starting point from which to examine small state foreign policy behaviour. However, the foreign policy of particular state is influenced by each of these abovementioned variables. Some have more impact and other have less. This situation differs in time and space. In a particular time period, for instance, individual variables are more prominent than - let's say - systemic variables and vice versa. Nonetheless, they can differ from state to state too. In this regard, for Kosovo, among other variables influencing its foreign policy, external environment of systemic variables seem to dominate. In other words, systemic variables will be considered as key explanatory factors in explaining foreign policy of Kosovo.

\subsection{Kosovo foreign policy objectives}

Kosovo Ministry of Foreign Affairs, as a leading institution of Kosovo's foreign policy, has achieved minimal results since its establishment in 2008. None of the declared short-term objectives of the MFA has been accomplished within this period. This argument increases doubts on the capacities of this Ministry to carry out the tasks assigned to it. Objectives such as: the recognition of the state of Kosova by a majority of UN member countries, recognition of the state of Kosova by all EU countries, presentation and representation of Kosova in countries hosting various sessions of international organizations or the building of an effective consular service in all countries with a significant presence of Kosova Diaspora, (Kosovo Foreign Objectives, 2009)remains wishes, rather than objectives that have marked any significant progress.

Since its independence, Kosova has been formally recognized by 98 out of 193 United Nation (UN) members, (50.7\%) and 22 out of 27 European Union (EU) Member states, (81.5\%) (Kosovo Ministry of Foreign Affairs, 2013). However, this is not a sufficient condition to become part of any of these organizations. Kosovo failed to establish contractual relationships with the EU institutions and to commence the due process of membership in this organization. The EU member countries that have not recognized Kosova - Spain, Greece, Cyprus, Slovakia and Rumania - and other countries too - justified their decisions not to recognize Kosovo with the argument that they were waiting for the advisory opinion of the International Court of Justice (ICJ). Regrettably, the Kosovo Ministry of Foreign Affairs was unprepared for the stage following the opinion of the ICJ (July 2010) and missed the opportunity to lobby strongly in countries that have not recognized Kosovo for fear that this would violate the principles of the international law, stipulating that this argument is no longer valid and therefore, ask for the recognition of these states. This result becomes even more disappointing when is considered that the recognitions did not followed the advisory opinion of the ICJ which concluded that the declaration of independence of 17 February 2008 did not violate general international law, Security Council resolution 1244 (1999) or the Constitutional Framework. Consequently the adoption of that declaration did not violate any applicable rule of international law (International Court of Justice, 2010).

\section{3 Kosovo and international organizations}

Being part of relevant international and regional organization is at high importance for every state. Scholars studying small state foreign policy, one of the behaviours they identified is that: states tend to secure multinational agreements and join multinational institutions whenever possible (Hey, 2003). Jeanne Hey argues that one of the most systemic features to most of the small states is that they engage in international organizations and draw on global regimes, laws, and norms to enhance their political influence and economic prosperity. For instance, "Gambia has used international linkage to create legitimacy for a regime that lacked it; Jordan has skilfully taken advantage of the changing regional alliances to keep itself safe, protect its interests and build a diplomatic reputation" (Hey, 2003, p. 6) In this regard, the systemic 
variables are to be considered as key explanatory variables which dominated and influenced Kosovo foreign policy as well.

International integration is an increasingly common global phenomenon among all states. Sometimes it is difficult to conclude whether small states really use it more than nonsmall states do. Kosovo achieved to be part of some of the important international organizations, such as: The World Bank (WB), International Monetary Fund (IMF), International Bar Association and International Road Transport Unit. Nonetheless, Kosovo still is not member of two most important world organizations to which it aims to adhere: United Nations and European Union. Since five (5) countries from EU did not recognized Kosovo independence yet, Kosovo cannot become member of EU. The same is for UN. In these circumstances, Kosovo diplomacy should analyse other possible alternatives to make Kosovo a fait accompli in international relations and to have direct recognitions from as many countries as possible. This would allow easier movement of Kosovo citizens and trade. In this regard, Ministry of Foreign Affairs should not focus only on countries which are member of UN and which did not recognized Kosovo, but should make clear before international community that the reality of Kosovo independence is irreversible because the state has more bilateral or multilateral agreements and is member of a lot of other organizations with a significant impact.

One possibility which is worthy considering is the application of Kosovo to become the $55^{\text {th }}$ country of Commonwealth of Nations. The objectives of this organization are in full compliance with the Constitution of Kosovo emphasising values such as: peace, freedom, democracy and human rights as the main principles. What is important, becoming member of this organization it is not a necessary condition to be former British Colony, because there are already two countries who are members of the organization and who were not British colonies: Mozambique (former Portuguese domain who become member since 1995) and Rwanda (former Belgian colony who become member since 2009) (Commonwealth of Nations, 2010). From the least meeting of the Commonwealth leaders in Kampala in 2007, the opportunity for countries which do not have historical connections with Great Britain to be part of this organization is opened even more. Two of former French colonies, Algeria and Madagascar, have applied for membership. Beside, Georgia and Eritrea have already expressed their interest to be part too. Membership in the Commonwealth will offer Kosovo a lot of opportunities to get closer with countries which have not recognize Kosovo independence yet and, by doing so, to compensate the lack of UN membership, in this way to be able to push forward its foreign policy goals and accomplish its objectives.

The second obstacle for Kosovo in the field of international relations is the fact that five member states of EU did not recognized its independence and, as a consequence, there is no contractual relationship with this organization which will open Kosovo the possibilities for membership. One of the arguments which make clear the real difficulties of Kosovo to become member of this organization is illustrated in the declaration of Cyprus when it claimed that: "it will not recognise Kosovo's Independence even if Serbia does so" (Sebastian, 2010). One possible way to somehow compensate the current inability to become member of the EU could be to negotiate for membership in the European Free Trade Association (EFTA) ${ }^{3}$. Member of this organization have an agreement with EU since 1994 to establish the European Economic Area, which allows members to enjoy the European common market and free circulation of people, goods and capital, without being members of the EU. Thus, through membership in EFTA (where all members already recognized Kosovo as an independent state) can be assured most of the benefits that will come from EU membership.

It is also necessary that Kosovo, except International Monetary Fund (IMF) and Word Bank (WB), to become member of other intergovernmental organizations such as: International Committee of Red Cross and Red Crescent of the European Space Agency. In international relations today, considerable space achieved to take non-state actors. If you gain respect from these kinds of actors; consequently, the image of Kosovo in international relations will be consolidated and its relative power to influence other countries will be increased too.

\footnotetext{
${ }^{3}$ The European Free Trade Association (EFTA) is an intergovernmental organisation set up for the promotion of free trade and economic integration to the benefit of its four Member States. The European Free Trade Association (EFTA) was founded in 1960 on the premise of free trade as a means of achieving growth and prosperity amongst its Member States as well as promoting closer economic co-operation between the Western European countries. Furthermore, the EFTA countries wished to contribute to the expansion of trade in the world at large. EFTA was founded by the Stockholm Convention in 1960. EFTA was founded by the following seven countries: Austria, Denmark, Norway, Portugal, Sweden, Switzerland, and the UK. Finland joined in 1961, Iceland in 1970, and Liechtenstein in 1991. In 1973, the UK and Denmark left EFTA to join the EC. They were followed by Portugal in 1986, and by Austria, Finland and Sweden in 1995. Today the EFTA members are Iceland, Liechtenstein, Norway and Switzerland (The European Free Trade Association, 2010).
} 
Kosovo can be certified more as a subject in international level, if signs and ratifies international treaties such as Ottawa or that of Kyoto against the pollution. In the case of Kyoto Protocol ${ }^{4}$ as signing members are listed even non-state territories such as Cook Islands, Niue and Palestine (Kyoto Protocol, 2010). As a conclusion, there are numerous possibilities and alternatives which enable the consolidation of Kosovo position in international relations, even when there are a lot of barriers encountered in the process of recognition by other countries in the road to become member of UN and EU.

International integration is an effective instrument that Kosovo as a small state need to use. This policy has to be promoted more and to be considered as a key foreign policy alternative. In this way Kosovo will open a lot of possibilities to increase its appeal to other states in globalized world. In this regard, most of the scholars argue that large states have greater chances of going it alone, if they choose so, whereas small states have a strong incentive to join organizations to enhance their relative power to achieve foreign policy goals (Hey, 2003).

\subsection{Kosovo diplomatic and consular missions}

The second short term objectives which Kosovo Foreign Ministry set as a priority is: building effective diplomatic and consular services in the states wherever there are a significant number of Kosovo citizens. The appointment of diplomatic staff for Kosovo Embassies was done based on law on the Ministry of Foreign Affairs and Diplomatic Services. According to this law, ambassadors and other members of the embassies have to be appointed by public announcement. This rare practice caused a lot of complications because ambassadors were appointed in standard procedures as other civil service staff are. Most of the appointed ambassadors are persons who used to live in the country where they serve for many years. This is considered problematic issue because they are connected with those countries more than is required to be. Some of them have even the citizenship of the country where they serve. By this, at least formally, they lose loyalty toward the serving country, Kosovo. Thus, most of the Kosovo Ambassadors are to be considered much more as: ambassadors of Kosovo Diaspora, rather than Kosovo's Ambassadors.

Traditionally small states like Kosovo with lack of human and financial resources do not need to have its own embassies in every country in the world. In the today world there are a lot of possibilities to have representation in most of the countries, without opening embassies there. Thus, the possibilities of small states today to be present on the international relations scene are enormous. Firstly, one of the possibilities is to entrust a friend country with representing the diplomatic and consular interests of small states in the rest of the world. For instance, countries like Andorra, Lichtenstein and Monaco accredited their diplomatic missions to neighboring countries only: France and Spain for Andorra: Austria and Switzerland for Lichtenstein and France for Monaco. One of these countries was then entrusted with representing their diplomatic and consular interests in the rest of the world (Kappeler, 2007). Same opportunity would be effective to be used by Kosovo too, Kosovo can entrust to some friend countries with great diplomatic networks with competences to represent Kosovo interest in countries where Kosovo don't have recourses to open embassies.

Another possibility is to use the so called 'system of joint diplomatic missions'. This is the case when two different independent countries - with great relationships among them and which share almost same interests - agree to open a joint diplomatic representation in a third country, where, on one hand, they use the same premises but, on the other hand, they represent different states. In this regard, Kosovo - with a mutual agreement - can agree on using the system of joint diplomatic missions together with Albania in many countries. This would compensate the Kosovo's lack of human and financial resources and, on the other hand, would create a lot of possibilities for Kosovo to have its representatives who will protect its interest in many countries.

Beside this, today information and communication technology (ICT) offers many possibilities to participate in international relations at a little cost and need of human resource (Kappeler, 2007). In this regard, one of the first steps toward meaningful international relations is to create a country website on the internet. On ministry web site - which have to be functional and updated - and through other links on it, important information and messages of a country can be easily accessible to interested governments, institutions and individual intent on dealing with that country.

Creation of so called "virtual embassies" and consulates is another possibility which small states can use order to reduce financial expenses, but, at the same time, to create and maintain diplomatic relations. "These are websites oriented toward specific countries and administrated by the sending foreign ministry” (Kappeler, 2007, p. 1). States do not

\footnotetext{
${ }^{4}$ The Kyoto Protocol is an international agreement linked to the United Nations Framework Convention on Climate Change. The major feature of the Kyoto Protocol is that it sets binding targets for 37 industrialized countries and the European community for reducing greenhouse gas (GHG) emissions. These amount to an average of five per cent against 1990 levels over the five-year period $2008-2012$ (Kyoto Protocol, 2010).
} 
have to send their staff physically to another state. Instead, the work is run from home country. In this case, the person who will be appointed in charge for bilateral relations will act as ambassador also. In this capacity, this person in charge will visit the receiving country from time to time with the aim of cultivating the necessary personal relationships with the latter's government and other interested circles.

These are some of the possibilities which Kosovo Ministry of Foreign Affairs can use in order to avoid disproportionate financial resources without losing the ability of creating functional diplomatic and consular missions abroad with the aim of protecting and promoting its interest through proactive foreign policy.

\section{Conclusion}

The research sought to examine Kosovo's foreign policy behaviour as an independent state. In addition, the study through the theoretical research and case study analysis aimed to identify which are sources of Kosovo's foreign policy and, furthermore, which of the identified sources are more dominant. Moreover, the analysis is focused in analysing the impact that the identified sources have in Kosovo's foreign policy behaviour.

The analysis permits some preliminary conclusions about explaining Kosovo foreign policy behaviour. As a small state, Kosovo's foreign policy was characterised by the tendency to join multinational agreements and institutions as much as possible with the aim of enhancing its political influence and economical prosperity.

The results of this paper have confirmed the hypothesis, respectively, if systemic variables - a category which is based on nonhuman aspects of a society's external environment, or in any other actions occurring abroad and influencing significantly choices made by officials (Rosenau, 2006) - predominates foreign policy of a country, then the ability of a small state to achieve its goals and objectives in international relation independently, without the help and support of other great state, are almost inexistent. The main variables which had significant impact in Kosovo's foreign policy appear to be systemic variables. In this regard, foreign policy of Kosovo is heavily constrained by systemic factors. Even though Kosovo's foreign policy agenda was focused on working for recognition of Kosovo by majority of UN member countries and by all EU countries, its Ministry of Foreign Affairs has achieved minimal results in this regard. The majority of recognitions of Kosovo's independence came as a result of intensive lobbing of western countries leaded by United States of America, and not by its abilities and capacities to persuade foreign countries to do so.

International integration is considered as a very effective instrument that Kosovo can use with the aim of finding new opportunities to increase its appeal to other states throughout the world and to push forward its national interests. Considering the obstacles that Kosovo is facing to become member of UN and EU, different alternatives have to be considered such as:

- Applying for membership on the Commonwealth of Nations. Values which characterise objectives of this organization are in full compliance with values of Kosovo Constitution emphasising: peace, freedom, democracy and human rights;

- Another potential way to compensate the current inability of Kosovo to become member of EU is to negotiate for membership in the European Trade Association (EFTA). Members of this organization have an agreement with EU since 1994 in establishing the European Economic Area, which allows members to enjoy the European common market and free movement of people, goods and capita, without being member of the EU;

- Today in international relations a considerable space is taking non-state actors. Thus, Kosovo, except that it has become member of IMF and WB, can consider the possibility to become member of intergovernmental organization too, such as: International Committee of Red Cross and Red Crescent of the European Space Agency;

- Kosovo can be certified more as a subject in international area if signs and ratifies international treaties such as: Kyoto Protocol against the pollution. In case of Kyoto as signing members are listed even non-state territories such as Palestine and Cook Islands;

Small states like Kosovo, with lack of financial and human resources do not need to open its own embassies in every country of the world. The possibilities of small states today to be present on international relation scene are enormous. With the aim of avoiding disproportionate financial expenses but without losing the ability to create effective and professional diplomatic and consular service which will protect and promote Kosovo's interest abroad, these opportunities can be used by Kosovo too.

- One of the possibilities is to entrust to a friend country with representing diplomatic and consular interests. For example, countries like Andorra, Lichtenstein and Monaco accredited their diplomatic missions to neighbouring countries only: France and Spain for Andorra: Austria and Switzerland for Lichtenstein and France for Monaco. 
One of these countries was then entrusted with representing their diplomatic and consular interests in the rest of the world (Kappler, 2007);

- To use the so called 'system of joint diplomatic missions'. This is the case when two different independent countries agree to open a joint diplomatic representation in a third country where they can use the same premises, but, in the same time, they represent different states. In this regard, Kosovo - with a mutual consent - can agree on using the system of joint diplomatic missions together with Albania in a third countries;

- Creation of so called 'virtual embassies' is another possibility that Kosovo as a small state can use. These are website oriented toward specific countries; states do not have to send their staff physically to another state. The work is run from the home country.

Thus, findings of the research suggest that Kosovo foreign policy from 2008 until 2012 was dominated by the issue of ensuring as many as possible recognition from different states with the final objective to become member of two most important international organizations: UN and EU. External sources came out to be the most important factors in shaping the state's foreign policy and influencing substantially its behavior. Since this variable was not the only source influencing Kosovo's foreign policy, even though dominated it, a suggestion for future alike studies would play important role in identifying in better way Kosovo's national interest which would be determinant platform in shaping Kosovo foreign policy behavior.

\section{References}

Berridge, G.R. (2005). Diplomacy: Theory and Practice. New York: Palgrave Macmillan.

Burnham, P., Lutz, K.G., Grant, W., Layton-Henry, Z. (2008). Research Methods in Politics. New York: Palgrave Macmillan. Roger, C. (2003). Kosovo: Where it All Began. International Journal of Politics, 17.1, pp. 167-182.

Hey, A.K. (Ed.). (2003). Small States in World Politics: Explaining Foreign Policy Behaviour. Colorado: Lynne Rienner. Hower, S.B. (2008). Do Small States Make Bad Allies?. USA: School of Arts and Science of the Catholic University of America. Judah, T. (2008). Kosovo: What Everyone Needs to Know. New York: Oxford University Press.

Kappeler, D. (2007). The Role of Diplomats from Small States. Diplofoundation, pp. 1-3.

Keohane O.R. (1969). Lilliputians' Dilemma: Small States in International Politics. InternationalOrganization, 23.2, pp. 291-310. Krause, V., Singler, D. (2001). Minor Powers, Alliance and Armed Conflict: Some Preliminary Patterns. In Erich, R., Gratner, H. (Eds), Small States and Alliances (pp. 15-25). New York: Physica-Verlag Heidelberg.

Maass, M. (2007). Small States from the Perspective of International Relations Theory: Realism and Liberalism Considered. Diplofoundation. pp. 1-13.

Peci, L. (2007). Kosovo's Foreign Policy: Strategic Factors, Objectives and Challenges. Kosovo's Foreign Policy: Kosovo's Post Status Foreign Policy. Prishtina: KFOS. pp. 9-55.

Rosenau, J.N. (2006). The Study of World Politics: Theoretical and Methodological Challenge. New York: Routledge.

Smith, N., Peace, M., Lee, D. (2005). Size Matters: Small States and International Studies. International Studies Perspectives, 6.3, pp. 395-7.

Steinmetz, R., Wivel, A. (2010). Small States in Europe: Challenges and Opportunities. London: Ashgate Publishing Limited.

Van Dijk, T. (1988). News as Discourse. London: Lawrence Erlbaum Associates.

Vayrynen, R. (1971). On the Definition and Measurement of Small Power Status. Cooperation and Conflict, pp. 91-102.

Yin, R.K. (2003). Case Study Research: Design and Methods. London: Sage Publications.

Constitution of the Republic of Kosovo. (2008). Prishtina: Kosovo.

International Court of Justice. (2010). Accordance with International Law of the Unilateral Declaration of Independence in Respect of Kosovo. Hague: Nederland.

Kosovo Declaration of Independence. (2008). Prishtina: Kosovo.

Law on Ministry of Foreign Affairs and Diplomatic Services of the Republic of Kosovo. (2008). Law No: 03/L-044. Prishtina: Kosovo.

Ministry of Foreign Affairs of Republic of Kosovo: General Objectives. (2008). Prishtina: Kosovo.

UNMIK. (2006). Regional Integration Key Agreements Driving Kosovo's Economic Development. Prishtina:Kosovo.

United Nations. (2007). Comprehensive Proposal for Kosovo Status Settlement. No: S/2007/168/Add.1Commonwealth of Nations. (2010,September 9).Retrieved: http://www.commonwealth-of-nations.org/The-Commonwealth-Introduction,2,2,1

GAP Institute. (2007) Kosovo's Foreign Policy. Prishtina: Institute for Advanced Studies GAP.

KMFAS Team: Kosovo Ministry of Foreign Affairs Support Project. (2010). Prishtina: USAID Kosovo. Kyoto Protocol. (2010, September 22). Retrieved: http://unfccc.int/kyoto_protocol/items/2830.php.

Commonwealth Advisory Group. (1997). A Future for Small States: Overcoming Vulnerability. Advisory Report . London: Commonwealth Secretariat. 
Sebastian, S. (2010, September 21). The ICJ on Kosovo and its Reprecussions for the EU. Retrieved:

http://www.euractiv.com/en/enlargement/icj-ruling-kosovo-and-its-repercussions-eu-analysis-496623.

The European Free Trade Association. (2010, September 10). Retrieved: http://www.efta.int/about-efta/the-european-free-tradeassociation.aspx.

The World Bank. (2010, July 21). Retrieved: http://web.worldbank.org/WBSITE/EXTERNAL/PROJECTS/ 0,,contentMDK: 21512464 pagePK:41367 piPK:51533 theSitePK:40941,00.html.

U.S. Department of State, Bureau of European and Eurasian Affairs, Background Note: Kosovo. (2010, November 14). Retrieved: http://www.state.gov/r/pa/ei/bgn/100931.htm. 